\title{
JOINING LIVING WOOD LEBENDES HOLZ VERBINDEN
}

$\nearrow$ FERDINAND LUDWIG // German translation: Christa Wendl and the author

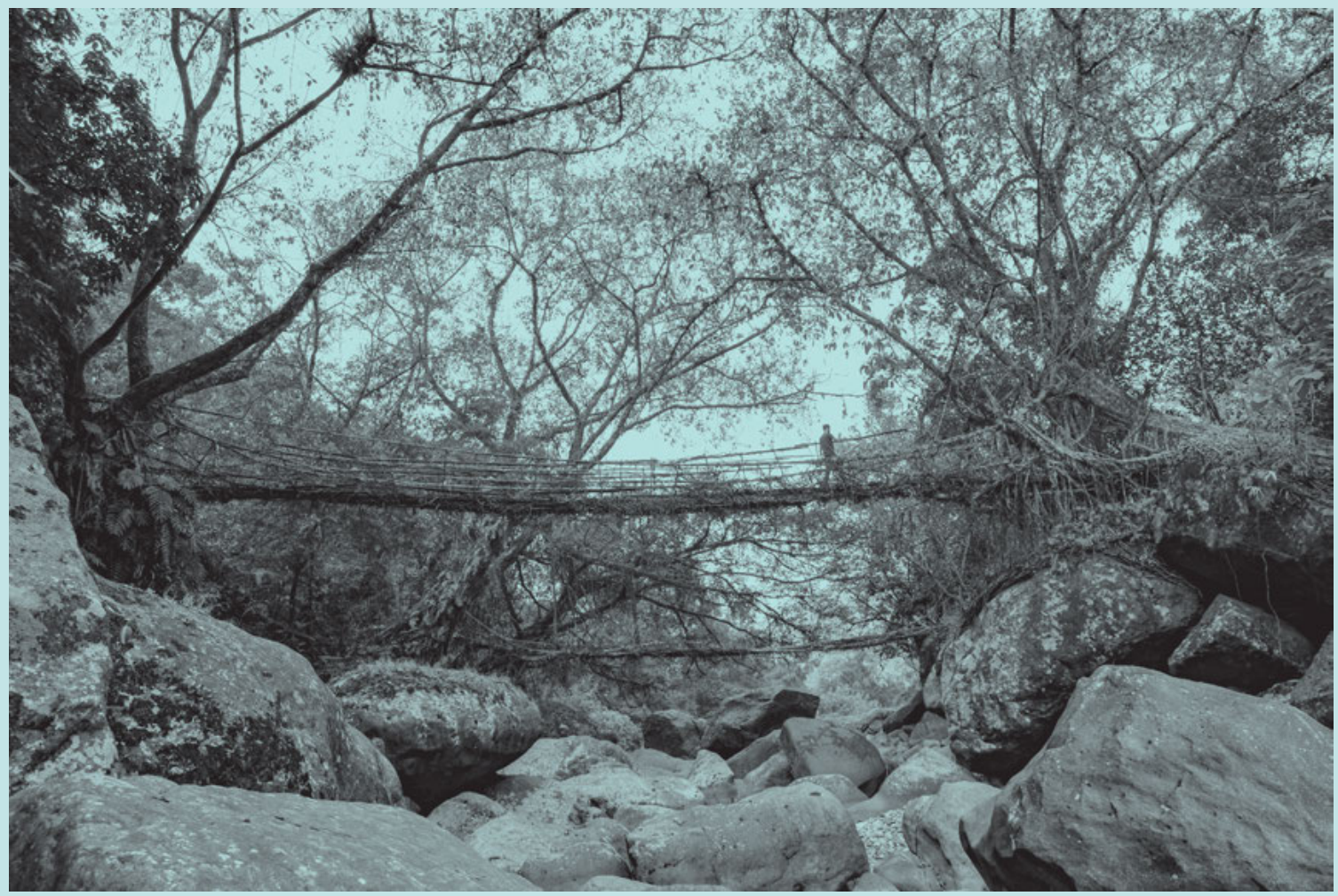

\ Fig. 1 | Abb. 1 :

A young and fully established Living Root Bridge in Meghalaya, India.

Photo (C) Ferdinand Ludwig

\section{INTRODUCTION}

In architecture, design with living trees, whereby living wood is used as a construction material, has a long tradition. For hundreds of years, the Khasi and Jaintia people of the hills of Meghalaya in Northeast India have been building living bridges. ${ }^{1}$ By guiding and connecting aerial roots of the Indian rubber fig (Ficus elastica), they make use of natural growth processes that create a stable, loadbearing structure over time (Fig. 1).

\section{EINFÜHRUNG}

Entwerfen mit lebenden Bäumen unter Verwendung von Holz als lebendem Baumaterial hat in der Architektur eine lange Tradition. Seit Hunderten von Jahren bauen die Khasi und Jaintia in den Hügeln von Meghalaya im Nordosten Indiens lebende Brücken. ${ }^{1}$ Durch das Formen und Verbinden von Luftwurzeln des indischen Gummibaums (Ficus elastica) machen sie sich natürliche Wachstumsprozesse zunutze und lassen so mit der Zeit ein stabiles Tragwerk entstehen (Abb. 1). 
Referring to these ideas, Baubota$n i k^{2}$ applies engineering methods to trees in order to create structures that can serve as three-dimensional elements that can potentially take over the functions of building components. With this in mind, a variety of techniques are being developed to train trees, joining them with each other and with non-living elements to create a biological-technical system. Based on botanical growth principles, organic joints can be established that use the trees' natural capacity to connect, called "inosculation." ${ }^{3}$

\section{BAUBOTANIK RESEARCH AND TEST FIELDS}

The scientific approach to this question is a central objective of the Baubotanik research group. The aim of the research is to base the construction and design of Baubotanik buildings on fundamental botanical growth rules. This requires the description and production of living plant stems as a technical material ${ }^{4}$ and the development of techniques for creating organic joints using inosculation. ${ }^{5}$ To address these questions, the Baubotanik research group and its partners set up a number of experimental buildings and a series of long-term inosculation tests (Fig. 2). One aim of the inosculation tests is to examine different tree species for applicability to Baubotanik and to create foundations for the development of practical joining techniques. ${ }^{6}$

For this reason, different joining techniques have been applied to ten species and multiple joint geometries. ${ }^{7}$ The applied joining techniques can be divided into three groups: techniques that bind plants together with wide and pliable ties that lay over the bark, techniques using thin ropes that cut into the bark while being incorporated into the growth process, and techniques in which the
Bezug nehmend auf diese Ideen nutzt die Baubotanik ${ }^{2}$ ingenieurwissenschaftliche Methoden, um aus Bäumen Strukturen zu schaffen, die als räumliche Konstruktionselemente potenziell die Funktion von Bauteilen in der Architektur übernehmen können. Um Bäume zu formen und sie untereinander und mit nicht-lebenden Elementen zu einem biologisch-technischen System zu verbinden, wurde eine Vielzahl an Techniken erprobt. Basierend auf botanischen Wachstumsprinzipien können organische Verbindungen erzeugt werden, die die natürliche Verwachsungsfähigkeit der Bäume nutzen. ${ }^{3}$

\section{FORSCHUNGS- UND}

TESTFELDER DER BAUBOTANIK

Die wissenschaftliche Bearbeitung dieser Frage ist ein zentrales Anliegen der Forschungsgruppe Baubotanik. Ziel der Forschung ist es, die Konstruktion und den Entwurf baubotanischer Gebäude auf elementaren botanischen Wachstumsregeln zu begründen. Dies erfordert die Beschreibung und Produktion von lebenden Pflanzenstämmen als technische Materialien ${ }^{4}$ sowie die Entwicklung von Methoden zur Herstellung organischer Verbindungen mit Hilfe von Verwachsungen. ${ }^{5}$ Um diesen Fragen nachzugehen, hat die Forschungsgruppe Baubotanik gemeinsam mit ihren Partnern mehrere Versuchsbauwerke errichtet und Langzeit-Verwachsungsversuche gelegt (Abb. 2).

Ein Ziel der Verwachsungsversuche ist es, verschiedene Baumarten auf ihre Eignung für die Baubotanik zu untersuchen und Grundlagen für die Entwicklung praxisgerechter Verbindungstechniken ${ }^{6}$ zu schaffen.

Im Zuge der Arbeiten wurden verschiedene Verbindungstechniken an zehn Baumarten und mehreren Verbindungsgeometrien ${ }^{7}$ angewendet.

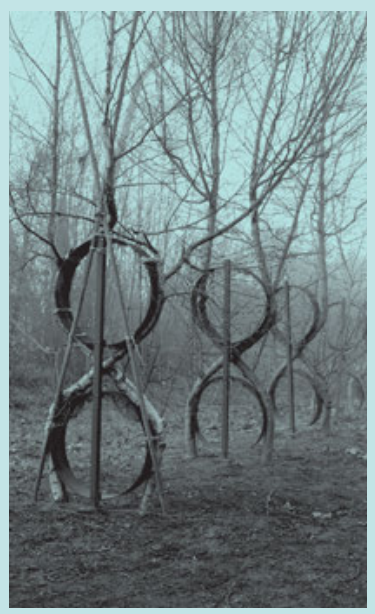

A Fig. 2 | Abb. 2:

Baubotanik test field at Bruns Nurseries, Bad Zwischenahn, Germany.

Photo (C) Ferdinand Ludwig 

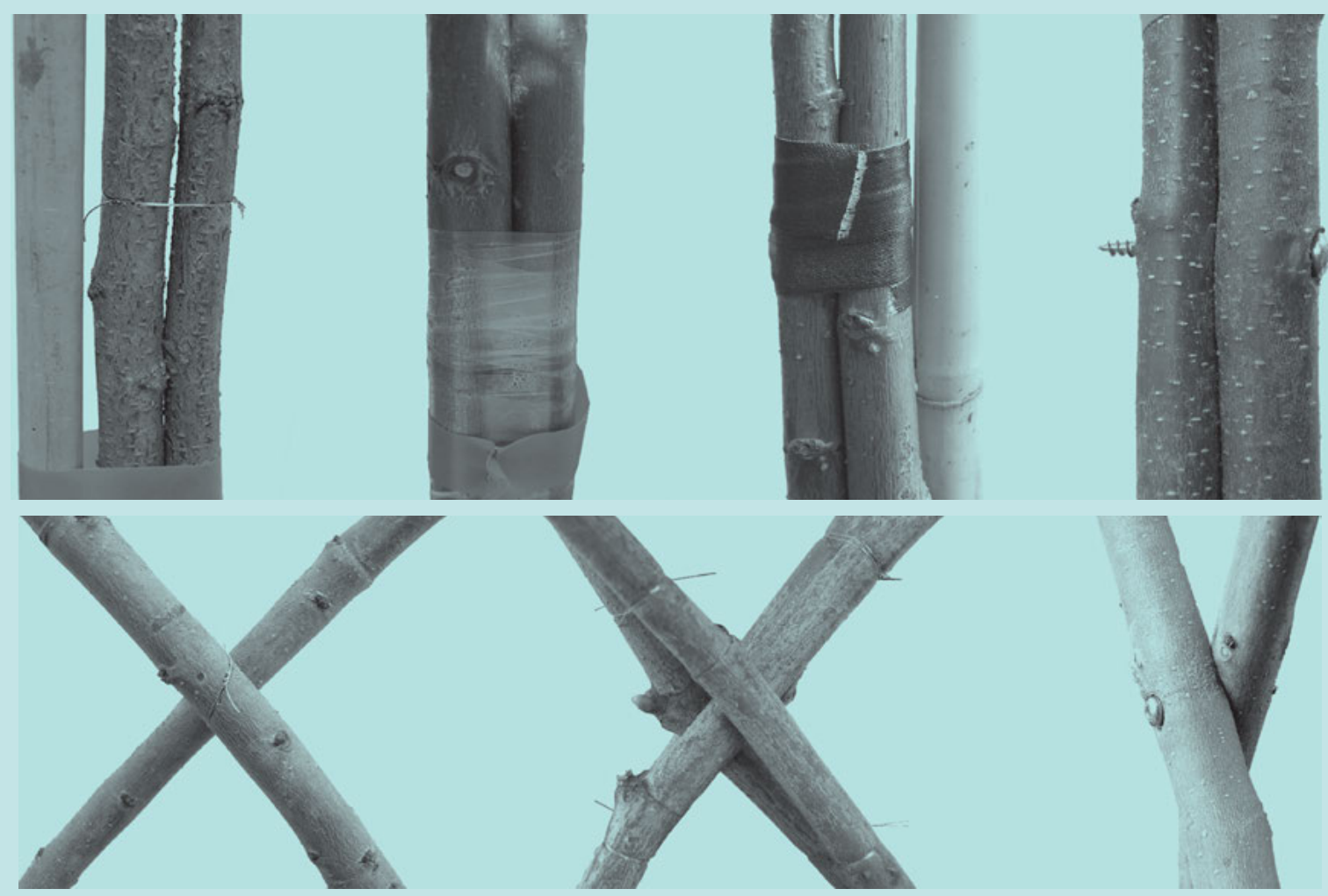

A Fig. 3 | Abb. 3:

Tests of different joining techniques used to develop practicable and plantcompatible inosculation methods.

Photo (C) Ferdinand Ludwig plants are connected by screws that penetrate the wooden core of the stems. Where possible and reasonable, these techniques were applied to all species and to parallel as well as crosswise connections, using between two to eight plants (Fig. 3).

The preliminary results show that the tendency to inosculate increases with the vigor of growth and decreases with the amount of secondary epidermal tissues (cork, bark). Species clearly differ in their reactions to the different joining techniques. The anatomy of the wood (circular or diffuse arrangement of the pores) and the ability of a species to partition and seal wounds are important factors in some joining techniques. The tests showed London plane to be the most applicable species because all joining techniques tested on it lead to good and fast inosculation results. Out of all these techniques, the screwing method has been proven as a very
Die eingesetzten Verbindungsmethoden lassen sich in drei Gruppen einteilen: Techniken, bei denen Pflanzen mit breiten und dehnbaren, über der Rinde liegenden Bändern miteinander verbunden werden; Techniken mit dünnen Seilen, die in die Rinde schneiden und dabei in den Stamm einwachsen; sowie Techniken, bei denen die Pflanzen durch den hölzernen Kern der Stämme durchdringende Schrauben miteinander verbunden werden. Soweit möglich und sinnvoll, wurden diese Techniken bei allen Baumarten und sowohl bei Parallel- als auch bei Kreuzverbindungen angewandt, wobei jeweils zwischen zwei und acht Pflanzen herangezogen wurden (Abb. 3).

Die vorläufigen Ergebnisse zeigen, dass die Neigung zu verwachsen mit der Wuchskraft zu- und mit dem Anteil der sekundären Abschlussgewebe (Kork, Rinde) abnimmt. Die Baumarten unterscheiden sich deutlich in 

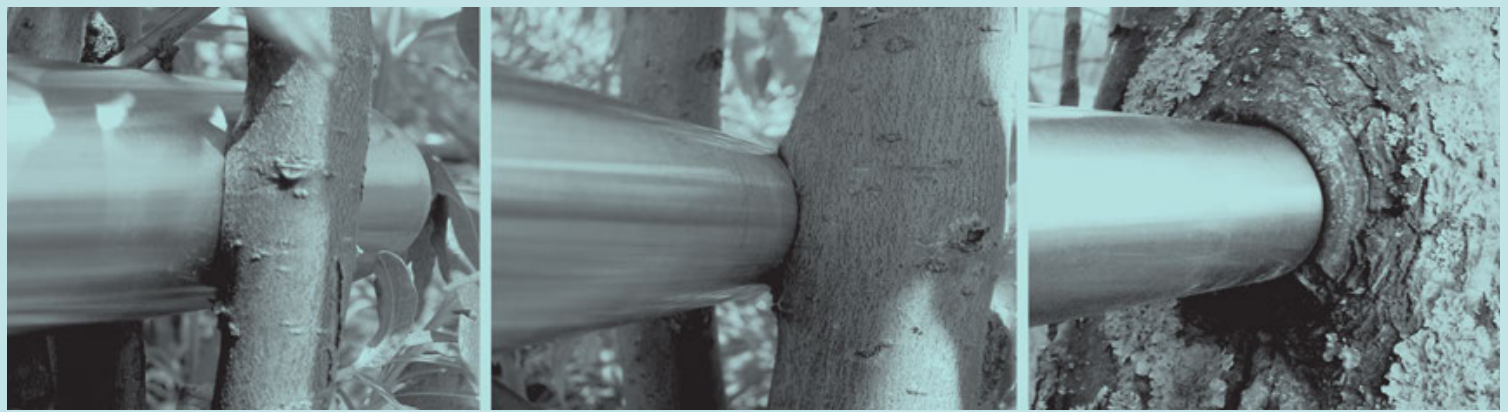

practicable, reliable and plant-compatible method. ${ }^{8}$

\section{BAUBOTANIK DESIGN APPROACH AND EXPERIMENTAL BUILDINGS}

In addition to these technical questions, Baubotanik calls for a new design approach, taking into account the processual character of the structures: their generic shape, appearance and spatial effect fundamentally change between seasons and over the years. This is demonstrated by the Baubotanik Footbridge, the Baubotanik research group's first 1:1 test building. The living columns of the bridge construction sprout in spring and summer, creating a dense wall of leaves that form a canopy over the footbridge. When the trees finally drop their leaves in fall, the building assumes an explicitly constructive appearance, which lasts through the winter months. Over time, the proportions of the building are changed by the growth of the canopy, while the main geometry remains constant, since trees show longitudinal growth only at the green, uppermost tips of the young branches, while the older parts only grow in circumference 9 , which is essential for Baubotanik structures. In the case of the footbridge, this is most noticeable in the junctions between the plant and the metal handrails, where the plants grow around stainless steel pipes, creating a tightly fitted joint that indi- ihrer Reaktion auf die verschiedenen Verbindungstechniken. So sind die Anatomie des Holzes (ringförmige oder diffuse Anordnung der Poren) und die Fähigkeit einer Baumart, Wunden abzuschotten und zu verschließen, wichtige Faktoren für die Anwendbarkeit einer Verbindungstechnik. Die Versuche zeigen, dass die geeignete Baumart ist, da alle an ihr getesteten Verbindungstechniken zu guten und schnellen Verwachsungsergebnissen führten. Von all diesen Techniken hat sich das Schraubverfahren als eine sehr praktikable, zuverlässige und pflanzenverträgliche Methode erwiesen. ${ }^{8}$

\section{ENTWURFSANSATZ UND \\ EXPERIMENTELLE BAU- BOTANISCHE BAUWERKE}

Neben diesen technischen Fragen erfordert die Baubotanik auch einen neuen Entwurfsansatz, der dem prozessualen Charakter der Bauwerke gerecht wird: Im Wechsel der Jahreszeiten und im Verlauf der Jahre verändern sich die ursprüngliche Form, das Erscheinungsbild und die räumliche Wirkung der Bauten grundlegend. Deutlich wird dies zum Beispiel an dem Projekt Baubotanischer Steg, dem ersten 1:1-Versuchsbauwerk der Forschungsgruppe Baubotanik. Hier treiben die lebenden Pflanzenstützen im Frühjahr und Sommer aus und bilden eine dichte Blätterwand und ein Dach über dem Steg. Wenn im ahornblättrige Platane die am besten
A Fig. 4 | Abb. 4 :

Development of the connection between the stainless steel handrail and the living structure of the Baubotanik Footbridge from 2005 to 2012.

Photo (C) Ferdinand Ludwig 


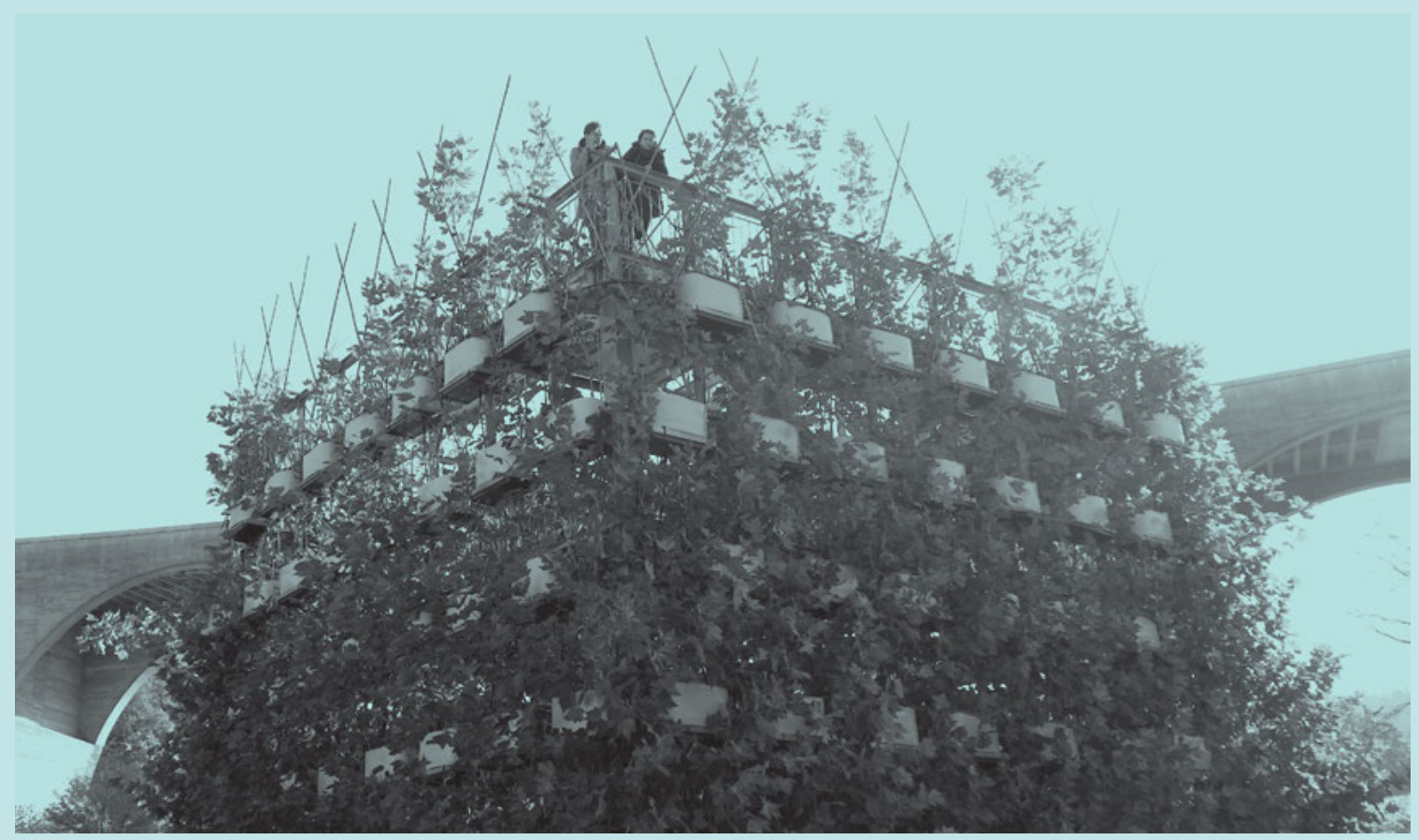

$\Delta \mathbf{\Delta}$ Fig. 5 | Abb. 5 :

Left: Plane Tree Cube in Nagold, Germany by OLA Office for Living Architecture. Right: Joint trees that will develop into the main loadbearing structure.

Photos (C) Ferdinand Ludwig cates the increasing stability of these connections (Fig. 4).

While the Baubotanik Footbridge investigates the incorporation of non-living elements into the living structure through overgrowth, other prototypes experiment on inosculations between plants, developing the traditional Khasi approach. The Plane Tree Cube is a Baubotanik building that was realized in 2012 in the context of a horticultural show in Nagold (southern Germany) as an experimental building that demonstrates the potential of the plant-addition technique $^{10}$ (Fig. 5). This technique was developed by the Baubotanik research group and is based on the fact that trees have the ability to compensate for the loss of organs by generating new ones, either in the same locations or elsewhere. If several plants are inosculated and thereby merge into one organism, the former individual ones no longer require all of their biological parts. This means that the roots or the leaves, or even both, can be removed, provided that
Herbst die Blätter von den Bäumen fallen, nimmt das Bauwerk ein ausgesprochen konstruktives Aussehen an, das bis in die Wintermonate anhält. Im Lauf der Zeit verändern sich die Proportionen der Konstruktion durch das Wachstum des Kronendaches, während die Grundgeometrie erhalten bleibt. Der Grund dafür ist, dass Bäume nur an den grünen, obersten Spitzen der jungen Äste ein Längenwachstum aufweisen, während die älteren Teile nur im Umfang ${ }^{9}$ zunehmen, was ein wesentlicher Aspekt baubotanischer Projekte ist. Im Fall des Stegs wird dies insbesondere an den Verbindungen zwischen Baumstütze und den Metallhandläufen deutlich, wo die Pflanzen um die Edelstahlrohre herumwachsen und so eine formschlüssige Verbindung schaffen, wodurch die Stabilität dieser Verbindungen zunehmen kann (Abb. 4).

Während beim Baubotanischen Steg die Einbindung von nicht-lebenden Elementen in die lebende Struktur durch Einwachsen untersucht wird, wird bei anderen Prototypen mit Ver- 


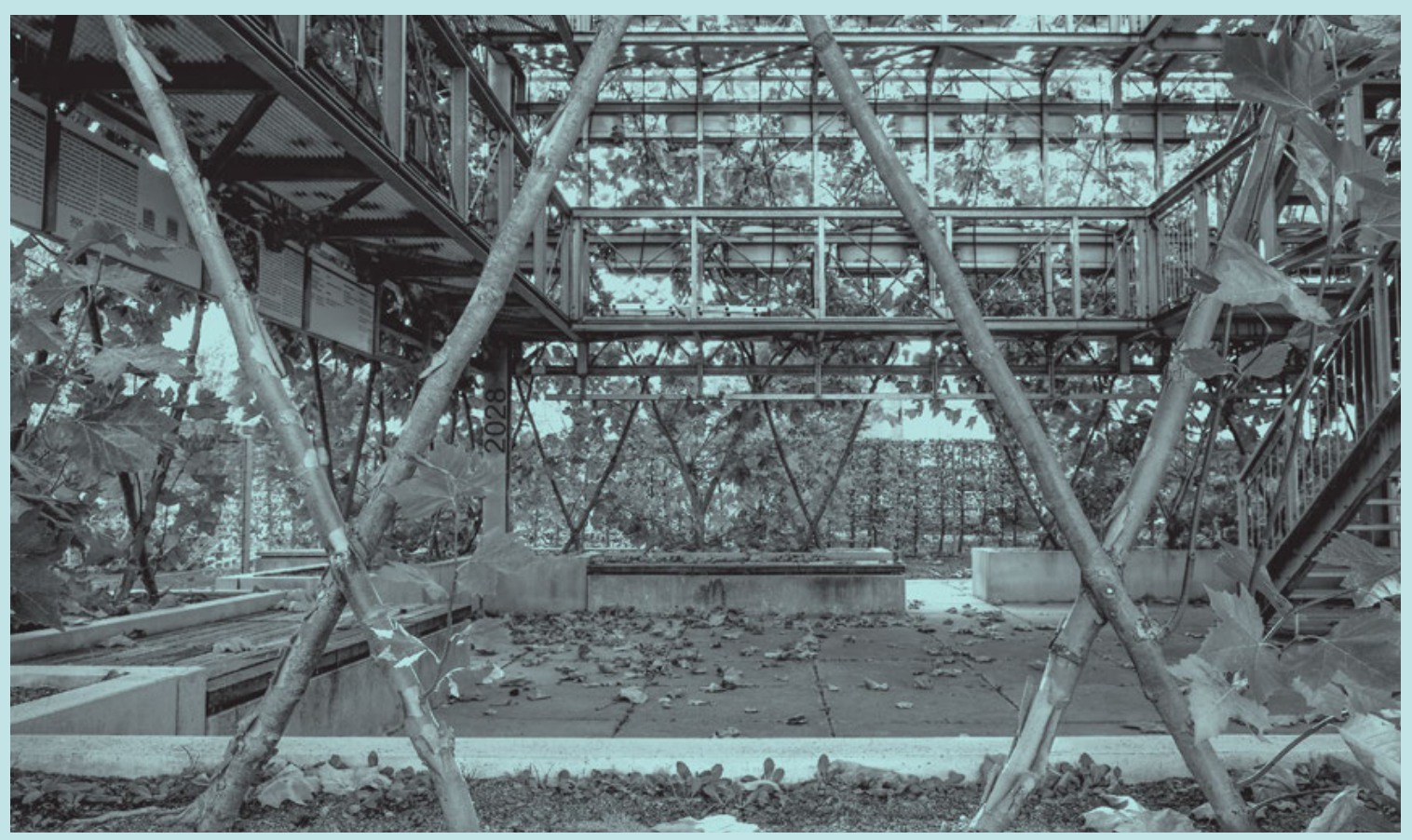

the inosculated structure as a whole can compensate for the loss. The plant-addition technique uses young plants that are arranged in space above and adjacent to each other and connected in such a way that they merge into one network-like plant structure. Only the lowest plants are planted in the ground, all others are planted in special containers with an automated system that continuously supplies them with water and nutrients to allow them to grow. As the network develops, the roots embedded in the ground that have more space to exploit additional resources grow more vigorously than those placed in the containers. Once the inosculations have developed, water and nutrients can be transported via the artificially created plant structure from the roots in the ground to the uppermost leaves, and the roots of the container plants become obsolete. Step by step, the high-level roots can be cut off, the automated watering system can be removed, and ultimately, the living structure becomes self-sufficient. Simultaneously, wachsungen zwischen Pflanzen experimentiert und der traditionelle Ansatz der Khasi weiterentwickelt. Der Platanenkubus ist ein baubotanisches Bauwerk, das 2012 im Rahmen einer Gartenschau in Nagold (Süddeutschland) als Experimentalbau realisiert wurde und das Potenzial der Pflanzenaddition $^{10}$ demonstriert (Abb. 5). Diese von der Forschungsgruppe Baubotanik entwickelte Technik basiert auf der Tatsache, dass Bäume die Fähigkeit besitzen, den Verlust von Organen zu kompensieren, indem sie an gleicher oder anderer Stelle neue Organe bilden. Verwachsen mehrere Pflanzen miteinander und verschmelzen so zu einem einzigen Organismus, benötigen die ehemaligen Einzelpflanzen nicht mehr alle ihre biologischen Teile. Das bedeutet, dass die Wurzeln oder die Blätter oder sogar beide entfernt werden können, vorausgesetzt, die verwachsene Struktur als Ganzes kann den Verlust ausgleichen. Bei der Pflanzenaddition werden Jungpflanzen so im Raum über- und nebeneinander angeordnet und miteinander verbunden, dass sie zu einer 


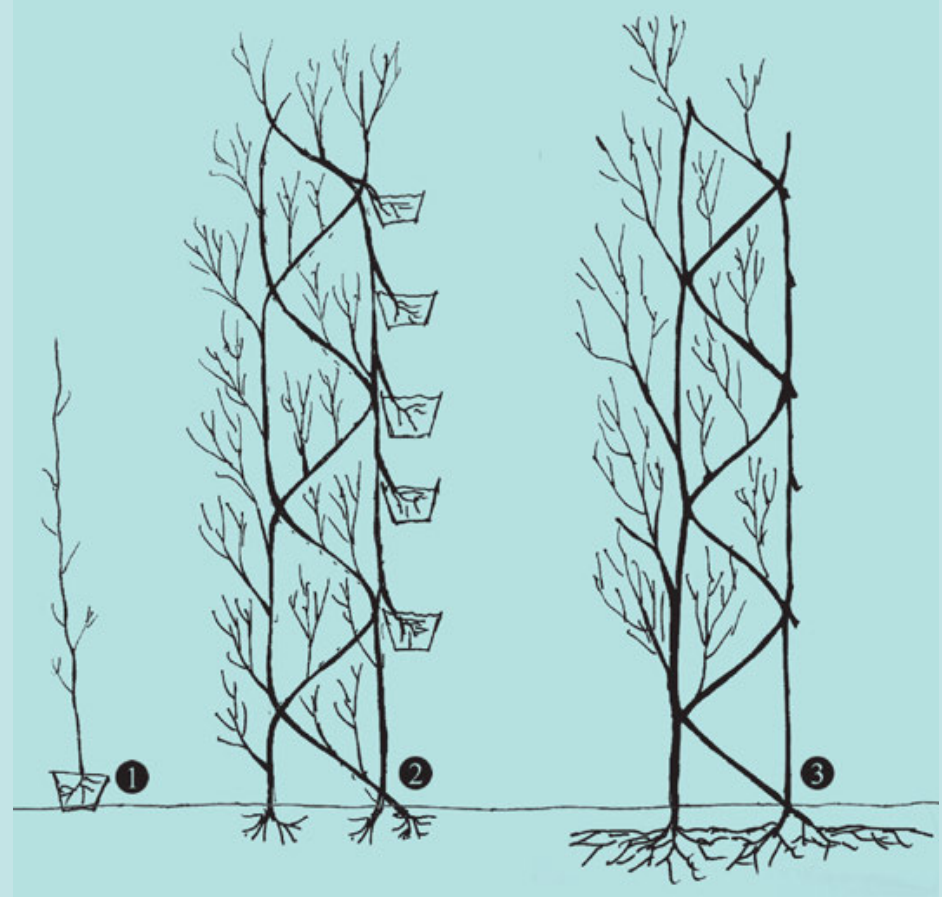

$\Delta$ Fig. 6 | Abb. 6:

The concept of plant addition, whereby multiple plants are joined to one organism.

(C) Ferdinand Ludwig the plant structure becomes stronger and eventually self-supporting due to secondary growth in circumference so that the scaffolding, which was initially required to support the containers and the young plants, can be removed"1 (Fig. 6).

\section{CONCLUSION}

Ultimately, the Baubotanik plantaddition approach demonstrates a completely new understanding of plants. The plant is no longer seen as a single biological entity with a naturally determined development path from sapling to tree, but rather as a living construction material or element, joined with other living material and technical elements to form a unified whole. This process allows for the immediate creation of living buildings on the scale of a fully grown tree, or - seen from another perspective - it leads to the construction of trees. On the other hand, the restrictions of natural growth, such as locally available resources, create netzartigen Pflanzenstruktur verschmelzen. Nur die untersten Pflanzen werden in den Boden, alle anderen in Pflanzgefäße gepflanzt. In diesen werden sie über ein automatisiertes System mit Wasser und Nährstoffen versorgt. Im Verlauf der Entwicklung wachsen die in den Boden gesetzten Wurzeln stärker als die Wurzeln in den Pflanzgefäßen, da sie über einen gröBeren Wachstumsraum verfügen und so zusätzliche Ressourcen erschließen können. Sobald sich die Verwachsungen etabliert haben, können Wasser und Nährstoffe über die künstlich geschaffene Pflanzenstruktur von den Wurzeln im Boden zu den obersten Blättern transportiert werden, und die Wurzeln in den Pflanzgefäßen werden obsolet. Sie können Schritt für Schritt entfernt werden, und das automatische Bewässerungssystem kann stillgelegt werden. Es entsteht eine autark lebensfähige Struktur, die durch sekundäres Dickenwachstum immer stabiler und letztlich selbsttragend wird. Dann können auch die anfangs zur Stützung der Pflanzgefäße und der Jungpflanzen erforderlichen Gerüste entfernt werden ${ }^{11}$ (Abb. 6).

\section{FAZIT}

Der baubotanische Ansatz der Pflanzenaddition führt zu einem völlig neuen Verständnis von Pflanzen. Die Pflanze wird nicht mehr als einzelnes biologisches Wesen mit einem von der Natur bestimmten Entwicklungsweg vom Sprössling zum Baum gesehen, sondern als lebendes Baumaterial oder Element, das sich mit anderen lebenden und technischen Elementen zu einem größeren Ganzen verbindet. Dieser Prozess ermöglicht die unmittelbare Schaffung von lebenden Bauwerken in der Größenordnung eines ausgewachsenen Baumes oder führt - aus anderer Perspektive betrachtet - zur Konstruktion von Bäumen. Gleichzeitig setzen limitierende Fak- 
limitations to the approach. From this viewpoint, Baubotanik fundamentally changes the way we use wood in architecture. Instead of felling trees to produce lumber, the living tree itself is integrated into architecture and thereby its ecological benefits as well: shading, cooling and purifying the air become integral parts of our built environment. toren des natürlichen Wachstums, beispielsweise die lokal verfügbaren Ressourcen, dem Ansatz Grenzen. Aus dieser Perspektive betrachtet verändert die Baubotanik die Art und Weise, wie wir Holz in der Architektur verwenden, grundlegend. Anstatt Bäume zur Holzgewinnung zu fällen, werden lebende Bäume selbst in die Architektur integriert und damit auch ihre ökologischen Vorteile: Verschattung, Kühlung und Luftreinigung werden zu integralen Bestandteilen unserer gebauten Umwelt.

1 Ludwig, F., Middleton, W. (2018): "Growing bridges", in: Grüntuch-Ernst, A. (ed.): Hortitecture - The Power of Architecture and Plants, Berlin: Jovis: 176-183; Ludwig, F., Middleton, W., et al. (2019): "Living bridges using aerial roots of Ficus elastica An interdisciplinary perspective", in: Scientific Reports 9(1): 1-11; Middleton, W., Habibi, A., et al. (2020): "Characterizing regenerative aspects of living root bridges", in: Sustainability 12(8): 3267.

2 en The term Baubotanik was developed at the Institute of Modern Architecture and Design (IGMA) at the University of Stuttgart. Founded in 2007, the Baubotanik research group was established as a transdisciplinary and inter-institutional network. After ten years of intense research, the subject was consolidated upon setting up the professorship Green Technologies in Landscape Architecture (GTLA) at the Technical University of Munich. The research group is embedded in an interdisciplinary network of researchers, designers and practitioners.

de Der Begriff Baubotanik wurde am Institut für Grundlagen moderner Architektur und Entwerfen (IGMA) der Universität Stuttgart entwickelt. Die Forschungsgruppe Baubotanik entstand 2007 als interdisziplinäres und interinstitutionelles wissenschaftliches Netzwerk. Nach zehn Jahren intensiver Forschung kam es mit der Einrichtung der Professur Green Technologies in Landscape Architecture (GTLA) an der Technischen Universität München zu einer Konsolidierung der Disziplin. Die Forschungsgruppe ist Teil eines interdisziplinären Netzwerks von Forschern, Entwerfern und Praktikern.

3 Ludwig, F., Middleton, W., et al. (2019b): "Baubotanik: Living wood and organic joints", in: Hudert, M., Pfeiffer, S. (ed.): Rethinking Wood: Future Dimensions of Timber Assembly, Basel: Birkhäuser: 262-275.

4 Ludwig, F., de Bruyn, G., et al. (2009): "Plant stems as building material for living plant constructions", in: Proceedings of the 6th Plant Biomechanics Conference, Cayenne, French Guyana, France: 398-405.

5 Ludwig, F. (2012): Botanische Grundlagen der Baubotanik und deren Anwendung im Entwurf, doctoral thesis, Universität Stuttgart: 300; Ludwig, F., Storz, O., et al. (2012): "Living systems: Designing growth in Baubotanik", in: Architectural Design Journal 82(2): 82-87.

6 en The focus here is on tree species commonly used in or native to central Europe. In contrast to the aerial roots of Ficus elastica, which are very flexible and inosculate very easily, the stems of these species have to be connected in a technical way to initiate the inosculation process.

de Der Fokus liegt hier auf Baumarten, die in Mitteleuropa gebräuchlich oder heimisch sind. Im Gegensatz zu den Luftwurzeln von Ficus elastica, die sehr flexibel sind und zum Verwachsen neigen, müssen die Stämme dieser Arten auf technische Weise verbunden werden, um den Verwachsungsprozess zu stimulieren.

7 en The species chosen in a first test series were: white willow (Salix alba), silver birch (Betula pendula), black alder (Alnus glutinosa), black locust (Robinia pseudoacacia), London plane (Platanus acerifolia), European ash (Fraxinus excelsior), Norway maple (Acer platanoides), English oak (Quercus robur), common hornbeam (Carpinus betulus) and common beech (Fagus sylvatica).

de Die in einer ersten Testreihe ausgewählten Arten waren: Silberweide (Salix alba), Sandbirke (Betula pendula), Schwarzerle (Alnus glutinosa), Gewöhnliche Robinie (Robinia pseudoacacia), Ahornblättrige Platane (Platanus acerifolia), Gemeine Esche (Fraxinus excelsior), Spitzahorn (Acer platanoides), Stieleiche (Quercus robur), Hainbuche (Carpinus betulus) und Rotbuche (Fagus sylvatica).

8 Ludwig 2012: 300; Ludwig, Storz et al. 2012.

9 Ludwig, F., Storz, O. (2005): "Baubotanik - Mit lebenden Pflanzen konstruieren", in: Baumeister, Zeitschrift für Architektur 11(2005): 72-75.

10 Ludwig, F. (2016): "Baubotanik: Designing with living material", in: Löschke, S. K. (ed.): Materiality and Architecture, London: Routledge.

11 ibid 
